\title{
Correction to: An empirical assessment of baseline feature location techniques
}

\author{
Abdul Razzaq $^{1} \cdot$ Andrew Le Gear $^{2} \cdot$ Chris Exton $^{1} \cdot$ Jim Buckley ${ }^{1}$ \\ Published online: 31 March 2021 \\ (C) The Author(s) 2021
}

\section{Correction to: Empirical Software Engineering (2020) 25:266-321 \\ https://doi.org/10.1007/s10664-019-09734-5}

The article "An empirical assessment of baseline feature location techniques", written by Abdul Razzaq, Andrew Le Gear, Chris Exton, Jim Buckley, was originally published Online First without Open Access. After publication in volume 25, issue 1, page 266-321 the author decided to opt for Open Choice and to make the article an Open Access publication. Therefore, the copyright of the article has been changed to (C) The Author(s) 2021 and the article is forthwith distributed under the terms of the Creative Commons licence CC BY, which allows readers to copy, distribute and transmit the Article as long as it is attributed back to the author. Readers are permitted to alter, transform or build upon the Article, and to use the Article for commercial purposes. Please read the full licence for further details at http://creativecommons. org/licenses/by/4.0/.

The online version of the original article can be found at https://doi.org/10.1007/s10664-019-09734-5

Abdul Razzaq

abdul.razzaq@lero.ie

Andrew Le Gear

andrew.legear@horizon-globex.ie

Chris Exton

chris.exton@ul.ie

Jim Buckley

jim.buckley@ul.ie

1 Lero, CSIS Department, University of Limerick, Limerick, Ireland

2 Horizon Globex Ireland DAC, Limerick, Ireland 
Open Access This article is licensed under a Creative Commons Attribution 4.0 International License, which permits use, sharing, adaptation, distribution and reproduction in any medium or format, as long as you give appropriate credit to the original author(s) and the source, provide a link to the Creative Commons licence, and indicate if changes were made. The images or other third party material in this article are included in the article's Creative Commons licence, unless indicated otherwise in a credit line to the material. If material is not included in the article's Creative Commons licence and your intended use is not permitted by statutory regulation or exceeds the permitted use, you will need to obtain permission directly from the copyright holder. To view a copy of this licence, visit http://creativecommons.org/licenses/by/4.0/.

Publisher's note Springer Nature remains neutral with regard to jurisdictional claims in published maps and institutional affiliations. 